\title{
IMPACTS OF E-BANKING ON PERFORMANCE OF BANKS IN A DEVELOPING ECONOMY: EMPIRICAL EVIDENCE FROM BANGLADESH
}

\author{
Md. Nur Alam SIDDIK ${ }^{1}$, Gang SUN², Sajal KABIRAJ ${ }^{3}$, \\ Joghee SHANMUGAN ${ }^{4}$, Cui YANJUAN ${ }^{5}$ \\ ${ }^{1}$ School of Finance, Dongbei University of Finance and Economics, Dalian, China \\ Department of Finance and Banking, Begum Rokeya University, Rangpur, Bangladesh \\ ${ }^{2}$ School of Finance, Dongbei University of Finance and Economics, Dalian, China \\ ${ }^{3}$ Dongbei University of Finance and Economics, Dalian, China \\ ${ }^{4}$ Skyline University College, University City of Sharjah, UAE \\ ${ }^{5}$ Dalian Polytechnic University, Dalian, China \\ E-mails:1nasiddikbru@gmail.com; ${ }^{2}$ gangsun123@126.com (corresponding author); \\ 3skabiraj@dufe.edu.cn; ${ }^{4}$ jshanmugan@skylineuniversity.ac.ae; ${ }^{5}$ cuiyanjuan_dl@163.com
}

Received 19 September 2014; accepted 29 June 2015

\begin{abstract}
E-banking has become one of the most popular methods of banking that has experienced a considerable expansion during the last few years. However, there is relative dearth of empirical studies examining the impact of e-banking on performance of banks. Though e-banking is gaining acceptance in Bangladesh, impact of e-banking on bank's performance is yet to be established. This paper fills this gap. Using panel data of 13 banks over the period of 2003-2013, this study empirically investigated the impact of e-banking on the performance of Bangladeshi banks measured in terms of Return on Equity, Return on Assets and Net Interest Margin. Results from pooled ordinary least square analysis show that e-banking begins to contribute positively to banks' Return on Equity with a time lag of two years while a negative impact was found in first year of adoption. Empirical findings of this study is of greater significance for the developing countries like Bangladesh because it will invoke the attention of the bank management and policy makers to pursue such policies to expand e-banking. This study also contributes to empirical literatures by reconfirming (or otherwise) findings of previous studies.
\end{abstract}

Keywords: e-banking, return on equity, return on asset, net interest margin, pooled regression analysis, Bangladesh.

JEL Classifications: G21, L25, O31, L86.

\section{Introduction}

Financial markets and banking system of developed countries work in unison to increase the flow of funds from savers to borrowers while in developing countries financial markets are undersized and sometimes completely absent. Nonetheless, the banking sector plays a significant role in the process of economic acceleration of developing 
economies and thus studying performance of banking sector of developing nations is of greater significance. Revolution in information and technological innovations and its use in banking activities have led credence to transformation of manual system banking operations to technology based banking all over the world and in recent years information and communication technology (ICT) have been recognized as the heart of banking sector while for a robust economy banking sector is playing a significant role (Abubakar, Tasmin 2012). With such information technologies, e-commerce, e-business and financial services industry have increasingly become an essential ingredient of competitive business strategy and a strong catalyst for economic development across the world. Among other mechanisms, e-banking is the most prominent and popular one (Salehi, Alipour 2014).

The banking and financial service sector of Bangladesh has started a new era and as such "e-banking" is a relatively new phenomenon in Bangladesh. Specifically, banks in Bangladesh started to adopt e-banking system since 2001 (Rahman 2007). Thus, thirteen years back, banking service in Bangladesh was analogous. All banking transaction was done through hand written process which took much time and energy as well as work force to carry out the banking services. Ahmed and Islam (2008) discussed that Bangladesh had failed to grab the opportunity extended from e-business. Nevertheless, in last few years a number of private and public sector banks are adopting high level of technology and electronic banking system (Hasan et al. 2010). Kondabagil (2007) opined that a number of factors, including competitive costs, customer retention and improved overall performance of the banks, influence the decision regarding adoption of e-banking. The importance of such performance measurement is crucial for the banks who already have adopted e-banking system to monitor their progress as well as to the bankers who are considering in adopting such e-banking system. Generally, banks would be encouraged to adopt e-banking if they found that it has a positive impact on their performance.

In the context of Bangladesh there exist a few studies which focused on the e-banking issues and those are descriptive in nature. For example, Al-Amin and Rahman (2010) discussed and argued that the prospects of e-banking in Bangladesh depend on better IT infrastructure, internal network and country domain. Baten and Kamil (2010) identified several benefits of e-banking to Bangladeshi banking sector and also conclude that the customers of this country have not enough knowledge of e-banking which is a barrier to the expansion of e-banking in Bangladesh.

Thus, all the studies concerning e-banking in Bangladesh are descriptive in nature and no studies have been found to measure whether progressions are being made by the adoption of e-banking system. Therefore, to fill this gap, this paper aims at empirically investigate the effects of e-banking on performance of Bangladeshi commercial banks using a sample of 13 banks that have adopted e-banking system over the period of 2003-2013. The paper contributes to the empirical literatures by reconfirming (or otherwise) findings of previous studies done across the world. Empirical findings of this study have greater significance for the developing countries like Bangladesh because it will invoke the attention of bank management and policy makers to pursue such policies to expand e-banking system which ultimately will convey long term benefits for the entire banking industry of Bangladesh. 


\section{Literature review}

\subsection{Concept of e-banking}

E-banking means a system through which financial service providers, customers, individuals and businesses are able to access their accounts, do transactions and obtain latest information on financial products and services from public or private networks, such as the internet. For example, using intelligent devices such as personal computer, automated teller machines (ATMs) and personal digital assistant (PDA), customers access e-banking services and do their transactions with less effort as compared to the branch based banking. The term e-banking can be explained in different way from different perspectives. Nonetheless, researchers across the world have made extensive efforts to provide a precise and all-inclusive concept of e-banking.

The term "e-banking" refers to a method of banking through which customers are able to carry out their banking transactions electronically without visiting a bank branch (Simpson 2002). Among other benefits, e-banking saves time, customers need not to visit the bank branch and banks have the opportunity to enhance their customer base thereby experience improved profits (Okibo, Wario 2014). According to Basel Committee Report on Banking Supervision (2003), e-banking is to include the provision of retail and small value banking products and services through electronic channels as well as a large value electronic payment and other wholesale banking services delivered electronically. With respect to the field of banking and financial services, e-banking has been described as a product of e-commerce. According to Sokolov (2007), financial institutions, in addition to provide traditional banking products and services, can also facilitates a wider array of banking products and services that have been designed or tailored to shore up e-commerce. The most common and popular support services are: Electronic card; Phone and mobile bank; Call center; Home bank; Corporate bank and Internet bank.

In Bangladesh, to date, scope of e-banking is very limited. Some of the private commercial banks and foreign-owned commercial banks have offered internet banking, mobile/ tele-banking and online banking facilities in a closed network environment. Al-Amin and Rahman (2010) defined that e-banking is such a method through which customers are able to access their accounts and get information about updated products and services provided by banks with the help of a personal computer or other intelligent devices. They also mentioned that although there are some electronic products and services being offered by the banks, true e-banking system is yet to be developed. Existing form of e-banking in Bangladesh takes mainly internet banking, online banking and mobile banking. Among these forms of e-banking, Automated Teller Machines (ATM) and mobile banking are the most popular. Thus, as evident in the above empirical studies, different scholars have conceptualized e-banking from different dimensions. On the basis of literatures explained above, in this paper, we conceptualize e-banking as a method of banking which involves use of information and communication technologies to conduct banking operations. 


\subsection{Previous empirical studies}

It is rational that whether or not e-banking system proves correct and whether banks capture benefits of this new technology based banking will ultimately depend on their assessment of the profitability. If banks find that with adoption of e-banking system their financial performance improves, then there will have a positive impact on the investment in such technology based banking services.

There exist a number of empirical studies concerning the impact of adoption of ebanking on the performance. Some scholars observed positive impact, some observed negative while other researchers have drawn mixed conclusions. Positive conclusions: using a sample of 72 Spanish commercial banks and data over a period of 1994-2002, Hernando and Nieto (2007) found that impact of adoption of e-banking system takes time to contribute to performance of banks and for the sample banks authors found significant positive impact, after three years of adoption of e-banking system, of a transactional web site on financial profitability, measured in terms of Return on Equity (ROE) and Return on Assets (ROA), of the banks. In the context of Turkey, using data of 1996-2005 on thirteen banks Onay et al. (2008) examined the effects of internet banking on the financial performance of banks. In addition to employing the approach of Hernando and Nieto (2007), they have used specific and macroeconomic control variables in the analysis and found that e-banking has a positive impact on banks' ROE with a time lag of two years. Rahman (2007) studied impact of innovative technology on the profitability of the banks operating in Bangladesh and found that technology adopted banks experienced improved performance as they gain maturity. The limitation of this study is that author only showed the performance changes overtime but did not explained whether such changes are significant or not. Aduda and Kingoo (2012) established a positive relationship between e-banking and financial performance of banks by using Pearson Product-Moment Correlation Coefficient test. Using data of twenty seven banks over the period of 2006 to 2010, authors found that e-banking has strong and significant marginal effects on returns on asset in the banks operating in Kenya. Karimzadeh et al. (2014) investigated the impact of e-banking on the profitability of a bank in Iran. By using quarterly data over the period of 2004-2012, they found that expansion of e-banking has significant positive association to the profitability, measured in terms of ROA, of the sample bank. Using a sample of 10 banks' data over the period of 2002 to 2012, Rauf and Qiang (2014) measured the impact of e-banking on the performance of Pakistani commercial banks where the performance was measured in terms of Return on Assets, Return on equity and interest margin. Their empirical investigation revealed that e-banking has significant positive impact on margin, ROA and ROE of the recent adopters whereas for the early adopters significant positive impact on ROE and Margin but slightly on ROA. On the basis of findings, they conclude that banks can consider e-banking as a cost saving effective strategy to compete with the domestic and foreign banks given a well-managed monitoring and control over the risks involved in.

Negative conclusions: contrary to the empirical findings of positive impact of e-banking on the performance of the banks, many researchers found negative impact. Using a panel data of fifteen Jordanian banks for the period of 2000-2010, Al-Smadi and Al- 
Wabel (2011) studied the impact of e-banking on the performance of Jordanian banks. In their study, performance of banks was measured by ROE and two sets of control variables were used. Using pooled OLS regression technique they found significant negative impact of e-banking on financial performance of banks. The major limitation of this study is that authors did not look at ROE after a specific year of adoption of ebanking. Since adoption of e-banking technology involves cost, this might take time to recover cost and experience profits. On the other hand, in Indian context Malhotra and Singh (2009) studied the effects of internet banking on performance and risk of Indian commercial banks and found no significant relationship between the profitability and offering of internet banking.

Mixed conclusions: Oyewole et al. (2013) examined the impact of e-banking on bank performance in Nigeria. Using panel data of 1999-2010 for eight commercial banks, authors found that e-banking has significant positive impact on the banks performance measured in terms of Return on Assets (ROA) and Net Interest Margin (NIM). However, the study found no impact on ROE. Sadr (2013) conducted a cross country study on four banks of selected Asian countries. Controlling bank specific and macroeconomic variables, using a fully modified OLS; author empirically found that internet banking has contributed to improve ROE with a time lag of three years while a negative impact is observed for one year lagged. Onay and Ozsoz (2013) used panel data over the period of 1990-2008 of eighteen retail banks operating in Turkey and revealed that Internet banking adoption is positively associated with the level of profits, deposits and loans per branch. Their study also revealed that adoption of internet banking has a negative impact on bank profitability after 2 years of adoption. According to the authors, the reasons for such negative impact is internet banking increases competition and results in lower interest income.

It could be seen from the above explained empirical literatures that the impact of ebanking on the performance of banks provides mixed evidences and thus inconclusive. Therefore, it brings an open ground for the academicians, researchers, regulators and supervisors to know empirically the impact of e-banking on the performance of banks. Furthermore, no studies have been found to empirically examine the effects of e-banking on the performance of Bangladeshi banks. Hence our main objective is to fill this gap with a systematic and comprehensive analysis of the impact of e-banking on the performance of banks operating in a developing country, viz., Bangladesh.

\section{Methodology}

\subsection{Data sources and description}

We chose private commercial banks since they are the pioneer of e-banking in Bangladesh and have sound financial health as compared with public sector banks. According to Scheduled Bank Statistics produced by the Bangladesh Bank (2013), there are 39 private commercial banks of which 9 banks started operation in the mid of 2013 and thus for this nine newly commenced banks, no data was available for this period. Among the remaining 30 banks we approached 25 banks based on purposive sampling 
technique. To get the date of adoption of e-banking, questionnaires were sent to the respective banks' head office or MIS department through personal visits. Of the 25 banks contacted, 13 banks responded.

Accordingly we have compiled panel data of 13 private commercial banks from respective banks' audited annual reports over the period of 2003 and 2013. In Bangladesh, banks started to adopt e-banking system since 2001 (Hasan et al. 2010) and in last few years adoption of e-banking system by the banks has increased. Thus we have chosen the period of 2003 and 2013 with an expectation of finding a conclusive impact of adoption of e-banking on the performance of banks. Macroeconomic data have obtained from the World Bank data sheet (The World Bank 2013).

We have collected and compiled data for this study over the period of 2003-2013. Thus, by nature, it is a cross sectional data for a range of years and also a time series data. Therefore, present study's data is a pooled data. Accordingly, the Pooled ordinary least square (OLS) technique was conducted in this research which is also used in similar studies such as Al-Smadi and Al-Wabel (2011) and Oyewole et al. (2013).

\subsection{Variables selection}

\subsubsection{Dependent variables}

In this study, researchers made an attempt to empirically investigate the impact of ebanking on bank performance in the context of commercial banks operating in Bangladesh. Thus dependent variable of the study is Bank's performance. In order to measure bank's performance we use three proxy variables which have been used in most studies. A commonly used measure of bank's performance is Return on Equity, ROE (Abaenewe et al. 2013; Al-Smadi; Al-Wabel 2011; DeYoung et al. 2007; Onay et al. 2008). ROE measures the return earned on common stock holders' investment in the firm. It gives an explanation of how effectively shareholder's funds are being used by the management of the bank. Another good measure of bank performance is Return on Assets, ROA, which gives a picture about how effective the management of bank is in generating profits with its available assets. In their study Abaenewe et al. (2013), Dey (2014), Khrawish and Al-Sa'di (2011), Oyewole et al. (2013) have used ROA as a measure of the performance of banks. Favoring ROE Hall and Weiss (1967) as cited in Khrawish and Al-Sa'di (2011) argued that due to the existence of optimal borrowing level, ROA might vary among industries while ROE tend to equal and thus provides a better measurement. Since our study is based on the banking industry only, thus we use both the ROE and ROA to measure the banks' performance. To compute ROA and ROE, we use before-tax figures rather than after-tax figures because tax rates may differ across banks due to non-performance related factors such as ownership structure.

Apart from ROE and ROA, various scholars around the world used another measure, namely Net Interest Margin, NIM, as a proxy of bank performance. Onay et al. (2008) argued that Government intervention might inflate ROE which may lead to inconsistent results. To avoid such inconsistent result, a third measure, NIM, was used to measure the performance of banks. Raharjo et al. (2014) explain that the higher the level of NIM of a bank, the more the profitability is. We hold the same argument and use NIM as a meas- 
ure of bank performance. Net interest income is the difference between interest income and interest expense of the bank. Dividing this difference by total assets we get NIM.

Based on the empirical literatures explained above it is seen that different scholars used different single ratio to measure bank performance. In this study, in order to get a comprehensive result of bank performance we employed all three proxy variables; ROE, ROA and NIM to measure the bank performance.

\subsubsection{Independent variables}

Since the aim of this study is to investigate the impact of e-banking system on bank performance, thus e-banking is the independent variable. To measure it, following the work of Hernando and Nieto (2007), Onay et al. (2008) a dummy variable index, EBANK ${ }^{\mathrm{J}}$, was created which takes a value of one (1) if the bank has introduced e-banking in a particular year $t$; otherwise it takes a value of zero (0). EBANK ${ }^{\mathrm{J}}$ in this study is comprised of $\mathrm{EBANK}^{1}, \mathrm{EBANK}^{2}$, and $\mathrm{EBANK}^{3}$ and co-efficient of these $\mathrm{EBANK}^{1}, \mathrm{EBANK}^{2}$, and $\mathrm{EBANK}^{3}$ will explain the impact of e-banking on bank's performance.

\subsubsection{Control variables}

Several control variables are used in this study in order to isolate the impact of e-banking on banks' performance. We expect two sets of control variables, bank specific and macroeconomic determinants, to influence bank performance and hereby controlled for.

Bank specific variables used in this study are Liquidity (LIQDTY), credit risk (CR), capital (CAPTL), and size (SZ). Liquidity reflects a bank's ability to meet the short term obligations as they come due. The trade-off between liquidity and profitability is crucial to any organization. The more the liquid assets are, the lower the rate of return. We expect and assign a negative sign (-) to this variable. We measure liquidity by the ratio of total loans to total deposits of a bank. Credit risk is considered as one of the major sources of loss and thus it has, in general, a negative impact on the bank's profitability and therefore we expect a negative sign (-) with this variable. We use ratio of nonperforming loans to total loans as a measurement of CR. Size, SZ, signals the specific risk, although expected sign is ambiguous. According to modern financial intermediation theory, banks efficiency, derived from economies of scale, is associated with bank size which could imply that larger banks may experience higher profits if they do not conduct their business in a very competitive business environment (Flamini et al. 2009). Jahan (2012), Rao and Lakew (2012) observed a positive relationship between size and profitability of banks. Authors argued that due to economies of scale, large size banks were experiencing more profits as compared to small size banks, while in the context of Nigerian banking industry, Obamuyi (2013) observed negative relationship. Thus, there are mix evidences on the relationship between size and profitability of banks. We compute the logarithm of total assets of a bank to measure the size. According to Flamini et al. (2009), capital is an important determinant of a bank's profitability. Naceur and Goaied (2001) established a relationship between capital and profitability of a bank explaining that a bank with higher capital to assets ratio needs lower external financing which involve more cost and thereby by reducing excessive cost the bank will experience higher profitability. The ratio of equity to total assets is used to measure this variable and we expect a positive sign $(+)$. 
In addition to the bank specific variables, two macroeconomic variables, economic growth (RGDP) and inflation rate (INF) are used as control variables to control for the effects of macroeconomic conditions over the period of 2003-2013. Athanasoglou et al. (2008) argued that during economic slowdowns, bank's lending could reduce which in turn will lower the profitability of the bank. On the other hand, during economic booms, an economic condition where all sectors of an economy perform well, demand for loan could increase which may widen the interest margin of the bank. Trujillo-Ponce (2013) found a significant positive relationship between economic growth and profitability of the bank. Therefore, with an expectation of positive sign $(+)$, we measure RGDP by GDP growth of the country. Flamini et al. (2009) discussed that the impact of inflation on profitability of bank depends on whether inflation rate in future are anticipated or not. Having an anticipated inflation implies that banks can adjust their interest rates in a manner so that their revenue will more than their cost and therefore achieve higher profits. Trujillo-Ponce (2013) found a positive relationship between inflation and ROA of banks. Thus, in line with these empirical studies we expect a positive sign with this variable and measure inflation by the current inflation rate of the country.

\subsubsection{Empirical models}

Based on previous research works by Al-Smadi and Al-Wabel (2011), Onay et al. 2008, Oyewole et al. (2013) we adopt an empirical model, where bank performance, $B P_{i t}$, is measured by ROA or ROE or NIM for bank $i$ in year $t$, as follows:

$$
\mathrm{BP}_{i t}=\alpha_{0}+\theta_{t} \mathrm{MACRO}_{t}+\beta_{i} X_{i t}+\lambda_{i t} \mathrm{EBANK}_{i t}^{j}+\varepsilon_{i t} .
$$

In the above model $\mathrm{BP}_{i t}$ reflects the performance of bank $i$ in year $t$ (dependent variables). We measure $\mathrm{BP}_{i t}$ by three proxy variables: ROE, ROA and NIM. Following the work of Hernando and Nieto (2007); Onay et al. (2008), we employ EBANK ${ }^{J}$ which is the matrix of dummy variables that equals 1 if the bank $i$ adopt electronic banking in year $t$. Thus, EBANK ${ }^{1}$ is a dummy variable that takes 1 if bank $i$ adopt e-banking in year $t$ (that is, during the last 1 year); EBANK ${ }^{2}$ takes 1 if the bank adopted e-banking in $t-1$. Similarly, EBANK ${ }^{3}$ takes 1 if the bank adopted e-banking in $t-2$. Xit represents the matrix of bank-specific control variables for the bank $i$ in period $t . \mathrm{MACRO}_{t}$ is a matrix of macroeconomic control variables in Turkey which is measured by GDP growth rate and inflation rate of the country in year $t$. Xit is the matrix of bank specific control variables. $\varepsilon_{i t}$ is a disturbance error term with mean zero and constant variance. i,e., $\varepsilon_{i t}$ is independently and identically distributed as $\mathrm{N}(0, \sigma 2)$ and $\alpha_{0}$ is a bank fixed effect term that captures time-invariant influence specific to bank $i$. Co-efficient of the variables EBANK $^{J}$ was the main interest by the researchers in this study while other variables are incorporated as control variables. A summary of variables used in this study, their measurements and expected signs are provided in Table 1. 
Table 1. Summary of variables used and their specification

\begin{tabular}{llcc}
\hline \multicolumn{1}{c}{ Variable } & \multicolumn{1}{c}{ Measurement } & Legend & Expected sign \\
\hline Return on equity & Net profit(before taxes) / total assets & ROE & + \\
\hline Return on assets & Net profit (before taxes) / equity & ROA & + \\
\hline E-banking & $\begin{array}{l}\text { Dummy variable equal to one if the } \\
\text { bank offer e-banking and zero otherwise }\end{array}$ & EBANK & + \\
\hline Capital & Equity capital/ total assets & CAPTL & + \\
\hline Size & logarithm of total assets & SZ & + / - \\
\hline Credit risk & Nonperforming loans/ total loans & CR & - \\
\hline Liquidity & Total loans/total assets & LIQDTY & - \\
\hline Economic growth & GDP growth rate & RGDP & + \\
\hline Inflation & Current period Inflation rate & INF & + \\
\hline
\end{tabular}

\section{Empirical results and discussion}

\subsection{Descriptive statistics}

We present the descriptive statistics in Table 2 for the dependent and independent and control variables that provide some insights about the variables. In case of the variable ROE, we found a mean ROE of $19.80 \%$ with a maximum value of $36.9 \%$ and a minimum value of $1.7 \%$ and a standard deviation of $7.255 \%$ where standard deviation reflects variability involved in. From this, we can apparently see that, with the introduction of electronic banking in last few years, ROE of banks have been improved. Similar findings have been drawn in case of ROA with a maximum of $4.29 \%$, minimum $0.35 \%$ and a standard deviation of 0.7082196 .In case of NIM, we observe a maximum of $4.6 \%$, minimum $1.1 \%$ where the standard deviation is 0.8941 . Thus, it could be seen that Bangladeshi banks have been observed a good growth rate in their ROE.

Table 2. Descriptive statistics of variables used

\begin{tabular}{cccccc}
\hline Variable & Obs & Mean & Std. dev. & Min & Max \\
\hline ROE & 140 & 19.80443 & 7.255062 & 1.7 & 36.9 \\
\hline ROA & 140 & 1.647643 & 0.7082196 & 0.35 & 4.29 \\
\hline NIM & 136 & 2.992981 & 0.8941486 & 1.1 & 4.6 \\
\hline LIQDTY & 140 & 0.673325 & 0.054258 & 0.498298 & 0.776334 \\
\hline CR & 136 & 4.389375 & 3.081719 & 0.36 & 18.7 \\
\hline SZ & 141 & 10.97031 & 0.8120051 & 8.421123 & 12.40439 \\
\hline CAPTL & 139 & 0.076933 & 0.0245077 & 0.033429 & 0.154282 \\
\hline RGDP & 141 & 6.136879 & 0.3810533 & 5.3 & 6.7 \\
\hline INF & 141 & 7.555319 & 1.525049 & 5.4 & 10.7 \\
\hline
\end{tabular}


In case of liquidity of the banks, the minimum value is 0.498298 , the maximum value is 0.776334 and the standard deviation is 0.054258 . This could be attributed to the fact that Bangladeshi banks have experienced liquidity problems in last few years. CR has a mean value of 4.389375 and a standard deviation of 3.081719 where the minimum value is $0.36 \%$ and maximum value is $18.7 \%$. Thus, Percentage of Non-Performing Loans to Total Loans experienced a wider variation during the period of the study. Other variables, Size; Capital; GDP and Inflation observed a moderate level of standard deviation over the period of 2003-2013.

\subsection{Multicollinearity test}

In this study we are using empirical data of thirteen banks on ten variables over the period of 2003-2013. For such data multicollinearity might be an issue. As shown in Table 3, the highest variance inflation factor (VIF) is 1.37 and as suggested by Nachane (2006) that VIF $<10.0$ is acceptable. Thus, there is very low level of multicollineraity and such multicollinearity is not an issue.

Table 3. Values of variance inflation factors'

\begin{tabular}{ccc}
\hline Variable & VIF & 1/VIF \\
\hline SZ & 1.37 & 0.728097 \\
\hline CAPTL & 1.33 & 0.750909 \\
\hline LIQDTY & 1.27 & 0.784981 \\
\hline EBANK1 & 1.15 & 0.870849 \\
\hline CR & 1.14 & 0.876303 \\
\hline EBANK3 & 1.14 & 0.879261 \\
\hline EBANK2 & 1.13 & 0.887571 \\
\hline RGDP & 1.11 & 0.897339 \\
\hline INF & 1.06 & 0.946172 \\
\hline Mean VIF & 1.19 & \\
\hline
\end{tabular}

\subsection{Overall results and their discussion}

Our model explains $33.47 \%$ of the variations in ROE; $21.17 \%$ of the variations in ROA and $10.38 \%$ variations in NIM. F-value indicates that at least one of the independent variables is significantly related to the performance.

In Table 4 we present results of estimation using Pooled Ordinary Least Square regression model. Empirical findings indicate that e-banking has no significant impact on the performance of banks in the year of adoption (EBANK ${ }^{1}$ ), measured in terms of ROE, ROA and NIM. Rather, in the year of adoption; we found a negative co-efficient of ROE. This can be attributed to the fact that adopting e-banking system involves high cost on IT and modern technologies. In the case of $\mathrm{EBANK}^{2}$ we observe a positive, though not significant, improvement in the profitability measured by all three proxies. This indicates that in the following year of e-banking adoption, after recovering their investments in technologies, banks started to experience profits. 
Table 4. Estimated results with pooled OLS

\begin{tabular}{|c|c|c|c|c|c|c|c|c|c|}
\hline \multirow{3}{*}{$\begin{array}{l}\text { Explanatory } \\
\text { variables }\end{array}$} & \multicolumn{9}{|c|}{ Dependent variables } \\
\hline & \multicolumn{3}{|c|}{ ROE } & \multicolumn{3}{|c|}{ ROA } & \multicolumn{3}{|c|}{ NIM } \\
\hline & Coef. & $\mathrm{T}$ & $P>t$ & Coef. & $\mathrm{t}$ & $P>t$ & Coef. & $\mathrm{t}$ & $P>t$ \\
\hline EBANK $^{\mathbf{1}}$ & -2.190685 & -1.12 & 0.263 & .347097 & 1.64 & 0.103 & .2277674 & 0.81 & 0.418 \\
\hline EBANK $^{2}$ & 1.232111 & 0.64 & 0.525 & .2242242 & 1.07 & 0.287 & .2617652 & 0.94 & 0.347 \\
\hline EBANK $^{3}$ & 3.435872 & 1.84 & $0.069^{*}$ & .2005788 & 0.99 & 0.325 & .0514842 & 0.17 & 0.867 \\
\hline LIQDTY & 21.25022 & 1.86 & $0.065^{*}$ & 3.620498 & 2.93 & $0.004^{* * *}$ & -.7554379 & -0.46 & 0.648 \\
\hline $\mathrm{CR}$ & -.8717745 & -4.83 & $0.000^{* * *}$ & .0126027 & 0.64 & 0.521 & -.0673988 & -2.59 & $0.011^{* *}$ \\
\hline $\mathrm{SZ}$ & -2.135833 & -2.77 & $0.006^{* * *}$ & -.1784746 & -2.13 & $0.035^{* *}$ & .1729336 & 1.55 & 0.125 \\
\hline CAPTL & -53.06361 & -2.09 & $0.039^{* *}$ & 9.604102 & 3.48 & $0.001^{* * *}$ & 2.807865 & 0.78 & 0.435 \\
\hline RGDP & -.3468929 & -0.23 & 0.820 & -.0064612 & -0.04 & 0.969 & -.0303513 & -0.14 & 0.892 \\
\hline INF & -.4782444 & -1.37 & 0.174 & -.0338243 & -0.89 & 0.374 & -.0307662 & -0.60 & 0.550 \\
\hline cons & 42.48275 & 3.18 & $0.002^{* * *}$ & .5988395 & 0.41 & 0.680 & 2.104542 & 1.08 & 0.280 \\
\hline R-squared & \multicolumn{3}{|c|}{0.3347} & \multicolumn{3}{|c|}{0.2117} & \multicolumn{3}{|c|}{0.1038} \\
\hline Adj R-squared & \multicolumn{3}{|c|}{0.2865} & \multicolumn{3}{|c|}{0.1544} & \multicolumn{3}{|c|}{0.0366} \\
\hline F -Statistic & \multicolumn{3}{|c|}{$6.93(\mathrm{p}$-value $=0.0000)$} & \multicolumn{3}{|c|}{$3.70(p$-value $=0.0004)$} & \multicolumn{3}{|c|}{$1.54(p$-value $=0.1399)$} \\
\hline
\end{tabular}

Note: $*$ indicates significant at $10 \% ; * *$ indicates significant at $5 \%$ and $* * *$ indicates significant at $1 \%$.

In the second year following the e-banking adoption, we observe a significant positive impact on ROE. In case of impact on ROA and NIM we found, though not significant but positive impact. Thus, findings of this study imply that in the third year of adoption of e-banking, banks are experiencing positive profits progressively. Our findings correspond to the results of Hernando and Nieto (2007), Onay et al. (2008), and Oyewole et al. (2013). Our results are also in line with Rahman (2007) who studied impact of innovative technology on the profitability of the banks operating in Bangladesh and found that technology adopted banks experienced improved performance as they gained maturity.

Implication of findings is that e-banking has gradual positive impacts on performance of banks in developing countries and hence could contribute to the process of economic acceleration.

\section{Conclusions}

This study empirically investigated the impact of e-banking on the performance of banks operating in a developing country, viz., Bangladesh. Revolution in information and technological innovations and its use in banking activities have led credence to transformation of manual system banking operations to technology based banking all over the world though it is a relatively new phenomenon in Bangladesh. Bangladesh is advancing in the use of e-banking system as alternative channels of banking. However, little is known about the impact of adoption of innovative technology, namely e-banking 
on performance of Bangladeshi banks. This is a first ever study in the Bangladesh context and one of the first comprehensive approaches in this field analysing impacts of e-banking on the performance of banks.

By using panel data of 13 banks, which have adopted e-banking some time in between 2003-2013, researchers estimated the impact of e-banking on the performance of banks, measured by ROE, ROA and NIM. Empirical results of this study confirm some findings in earlier research that e-banking has gradual positive impacts on banks' performance. Findings of this study is more comprehensive and conclusive than earlier research since this study uses three different indicators namely ROA, ROE and NIM to measure banks' profitability whereas in the literature mostly a single measure of bank's profitability have been used. In addition, control variables such as liquidity have not been considered in the literature.

Our findings indicate that e-banking has had a positive impact on the performance of banks, measured in terms of ROE, in Bangladesh with a time lag of two years which is similar to the findings of other studies conducted in the context of developed countries. This study also reveals positive impact, though not significant, of e-banking on ROA and NIM. Findings suggest that during the year of adoption of e-banking, banks may experience negative profits. This is because of large investments in e-banking technologies at the one side and on the other side customers in developing countries are mostly accustomed with traditional branch-based banking and thus take time to adopt a new technology. However, empirical findings also suggest that following the year of adoption, banks would be able to recover their investments and hence experience profits. All control variables, except macroeconomic variables, have statistically significant influence on the profitability of Bangladeshi banks. Empirical findings suggest that credit risk has significant negative impact on ROE and NIM. Therefore, to reduce credit risk, managers of the banks should improve the process of screening and monitoring of credit risk which will in turn improve the level of profits. Significant relationship between liquidity and the ROE, ROA has also been observed. Findings also suggest significant negative influence of capital on the performance of banks, measured in terms of ROE and ROA. As with the effect of size, significant negative impact on ROE and ROA but positive impact on NIM has been observed during the period under study which is actually a non-uniform finding. As for the macroeconomic variables, we conclude that variables have no significant influence on performance of banks. Thus, we conclude that e-banking positively affect profitability of banks in developing countries and hence contributes to the process of economic acceleration of the same. Therefore, with this finding, this study encourages other banks in developing economies who have not adopted e-banking yet to introduce such banking system in order to experience improved profitability as this revealed in this study. However, bank management in developing countries should aware of several factors that could make e-banking unattractive. Among others, poor internet services, low literacy rate, political stability are mentionable. Also, banks should consider the level of risk associated with the adoption and usage of e-banking system. For example, banks should be able to ensure sufficient security to check the incidence of hacking by the hackers. The regulatory authority should provide appropriate framework to ensure efficient and secure transaction through e-banking system. 
Although we found a significant positive impact of e-banking on the ROE of sample banks, yet this study suffers from a comprehensive and systematic data base for all banks in Bangladesh. As more systematic data sets become available, we believe further research would be conducted on the same issue to confirm our findings.

\section{References}

Abaenewe, Z. C.; Ogbulu, O. M.; Ndugbu, M. O. 2013. Electronic banking and bank performance in Nigeria, West African Journal of Industrial and Academic Research 6(1): 171-187.

Abubakar, A. A.; Tasmin, R. B. H. 2012. The impact of information and communication technology on banks' performance and customer service delivery in the banking industry, International Journal of Latest Trends in Finance and Economic Sciences 2(1): 80-90.

Aduda, J.; Kingoo, N. 2012. The relationship between electronic banking and financial performance among commercial banks in Kenya, Journal of Finance and Investment Analysis 1(3): 99-118.

Ahmed, F.; Islam, M. T. 2008. E-banking: performance, problems and potentials in Bangladesh, Business Review 6(1): 20-28.

Al-Amin, S.; Rahman, S. S. 2010. Application of electronic banking in Bangladesh: an overview, Bangladesh Research Publications Journal 4(2):172-184.

Al-Smadi, M. O.; Al-Wabel, S. A. 2011. The impact of e-banking on the performance of Jordanian banks, Journal of Internet Banking and Commerce 16(2): 1-10.

Athanasoglou, P. P.; Brissimis, S. N.; Delis, M. D. 2008. Bank-specific, industry-specific and macroeconomic determinants of bank profitability, Journal of International Financial Markets, Institutions and Money 18(2): 121-136. http://dx.doi.org/10.1016/j.intfin.2006.07.001

Bangladesh Bank. 2013. Scheduled Bank Statistics [online], [cited 01 May 2014]. Available from Internet: http://www.bangladesh-bank.org/pub/quaterly/schbanksta/oct_dec_13/index.php

Basel Committee on Banking Supervision. 2003. Risk management principles for electronic banking, Bank for International Settlements [online], [cited 29July 2014].Available from internet: http://www.bis.org/publ/bcbs98.pdf.

Baten, M. A.; Kamil, A. A. 2010. E-banking of economical prospects in Bangladesh, Journal of Internet Banking and Commerce 15(2): 1-10.

Dey, M. 2014. Profitability of commercial banks in Bangladesh: a multivariate analysis, IOSR Journal of Business and Management 16(4): 92-95. http://dx.doi.org/10.9790/487X-16439295

DeYoung, R.; Lang, W. W.; Nolle, D. L. 2007. How the internet affects output and performance at community banks, Journal of Banking \& Finance 31(4): 1033-1060.

http://dx.doi.org/10.1016/j.jbankfin.2006.10.003

Flamini, V.; Schumacher, L.; McDonald, C. A. 2009. The determinants of commercial bank profitability in Sub-Saharan Africa. IMF Working paper No. 09/15. International Monetary Fund.

Hall, M.; Weiss, L. 1967. Firm size and profitability, The Review of Economics and Statistics 49(3): 319-331.

Hasan, A. S.; Baten, M. A.; Kamil, A. A; Parveen, S. 2010. Adoption of e-banking in Bangladesh: an exploratory study, African Journal of Business Management 4(13): 2718-2727.

Hernando, I.; Nieto, M. J. 2007. Is the Internet delivery channel changing banks' performance? The case of Spanish banks, Journal of Banking \& Finance 31(4):1083-1099.

http://dx.doi.org/10.1016/j.jbankfin.2006.10.011 
Jahan, N. 2012. Determinants of bank's profitability: evidence from Bangladesh, Indian Journal of Finance 6(2): 32-38.

Karimzadeh, D. S. D.; Emadzadeh, D. M.; Shateri, J. 2014. The effects of electronic banking expansion on profitability of a commercial bank (Sepah bank of Iran), Indian Journal of Scientific Research 4(6): 305-312.

Khrawish, H. A.; Al-Sa'di, N. M. 2011. The impact of e-banking on bank profitability: evidence from Jordan, Middle Eastern Finance and Economics 13: 142-158.

Kondabagil, J. 2007. Risk management in electronic banking: concepts and best practices, Vol. 454. Singapore: John Wiley \& Sons, 75-90. http://dx.doi.org/10.1002/9781118390436

Malhotra, P.; Singh, B. 2009. The impact of internet banking on bank performance and risk: the Indian experience, Eurasian Journal of Business and Economics 2(4): 43-62.

Naceur, S. B.; Goaied, M. 2001. The determinants of the Tunisian deposit banks' performance, Applied Financial Economics 11(3): 317-319. http://dx.doi.org/10.1080/096031001300138717

Nachane, D. M. 2006. Econometrics: theoretical foundations and empirical perspectives. $1^{\text {st }}$ ed. New Delhi: Oxford University Press, 26-32.

Obamuyi, T. M. 2013. Determinants of banks' profitability in a developing economy: evidence from Nigeria, Organizations and Markets in Emerging Economies 4(2-8): 97-111.

Okibo, B. W.; Wario, A. Y. 2014. Effects of e-banking on growth of customer base in Kenyan banks, International Journal of Research in Management \& Business Studies 1(1):78-84.

Onay, C.; Ozsoz, A. P. D. E.; Helvacioğlu, A. P. D. A. D. 2008. The impact of internet-banking on bank profitability-the case of Turkey, in Oxford Business \&Economics Conference Program, 22-24 June, 2008, Oxford, UK.

Onay, C.; Ozsoz, E. 2013. The impact of internet-banking on brick and mortar branches: the case of Turkey, Journal of Financial Services Research 44(2): 187-204.

http://dx.doi.org/10.1007/s10693-011-0124-9

Oyewole, O. S.; Abba, M.; El-Maude, J. G. 2013. E-banking and bank performance: evidence from Nigeria, International Journal of Scientific Engineering and Technology 2(8): 766-771.

Raharjo, P. G.; Hakim, D. B.; Manurung, A. H.; Maulana, T. N. 2014. The determinant of commercial banks' interest margin in Indonesia: an analysis of fixed effect panel regression, International Journal of Economics and Financial Issues 4(2): 295-308.

Rahman, M. M. 2007. Innovative technology and bank profitability: the Bangladesh experience, Working Paper No. 0803. Bangladesh Bank.

Rao, K. R. M.; Lakew, T. B. 2012. Determinants of profitability of commercial banks in a developing country: evidence from Ethiopia, International Journal of Accounting and Financial Management Research 2(3): 1-20.

Rauf, S.; Qiang, F. 2014. The integrated model to measure the impact of e-banking on commercial bank profitability: evidence from Pakistan, Asian Journal of Research in Banking and Finance 4(1): 25-45.

Salehi, M.; Alipour, M. 2014. E-banking in emerging economy: empirical evidence of Iran, International Journal of Economics and Finance 2(1):201-209.

Sadr, S. M. H. 2013. Consideration the effect of e-banking on bank profitability; case study selected Asian countries, Journal of Economics and Sustainable Development 4(11): 112-117.

Simpson, J. 2002. The impact of the internet in banking: observations and evidence from developed and emerging markets, Telematics and Informatics 19(4): 315-330.

http://dx.doi.org/10.1016/S0736-5853(01)00019-3 
Sokolov, D. 2007. E-banking: risk management practices of the Estonian banks, Working Paper No.156. Institute of Economics at Tallinn University of Technology.

The World Bank. 2013. World development indicators [online], [cited 16 July 2014]. Available from Internet: http://data.worldbank.org/country/bangladesh

Trujillo-Ponce, A. 2013. What determines the profitability of banks? Evidence from Spain, Accounting \& Finance 53(2): 561-586. http://dx.doi.org/10.1111/j.1467-629X.2011.00466.x

Md. Nur Alam SIDDIK received the PhD in Finance from Dongbei University of Finance and Economics, Dalian, China. He is an Assistant Professor in the Department of Finance and Banking, Begum Rokeya University, Rangpur, Bangladesh. His current research interests include, electronic banking and economic growth, performance analysis of banks, mobile banking and financial inclusion, bank led financial inclusion.

Gang SUN received the MS in Finance and Banking from Jilin University, China, and $\mathrm{PhD}$ in Finance from the same University. He was a Senior Fulbright Visiting Scholar in University of Washington. Currently, he is a Full Professor in the School of Finance, Dongbei University of Finance and Economics, Dalian, China. His current research interests include financial inclusion, mobile banking and economic developments, internet banking, modern economics and banking issues.

Sajal KABIRAJ is Full Professor of Strategy \& International Business with Dongbei University of Finance and Economics, Dalian, China. He is recipient of Best Teacher Awards in 2008 \& 2011 for teaching and research excellence. He has taught at postgraduate level in universities in Sweden, Austria, Malaysia, Canada, UAE, China and India. His current research interests include e-banking, information technology, technology adoption, and trust.

Joghee SHANMUGAN is Associate Professor with Skyline University College, Sharjah, UAE. His current research interests include adoption, consumer behaviour, diffusion of innovation, e-banking, and satisfaction.

Cui YANJUAN received her PhD from Dongbei University of Finance and Economics, China. She is an Associate Professor at Dalian Polytechnic University, China. Her research interests include financial inclusion, online banking, microfinance, financial development and international economics. 